\title{
Front Matter: Volume 8750
}

, "Front Matter: Volume 8750," Proc. SPIE 8750, Independent Component Analyses, Compressive Sampling, Wavelets, Neural Net, Biosystems, and Nanoengineering XI, 875001 (6 June 2013); doi: 10.1117/12.2031990

Event: SPIE Defense, Security, and Sensing, 2013, Baltimore, Maryland, SPIE. United States 


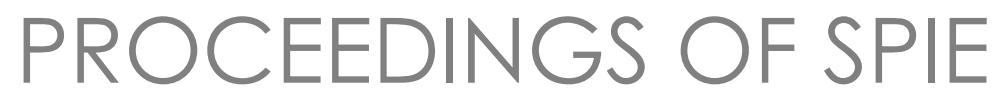

\section{Independent Component Analyses, Compressive Sampling, Wavelets, Neural Net, Biosystems, and Nanoengineering $X I$}

Harold H. SzU

Editor

1-3 May 2013

Baltimore, Maryland, United States

Sponsored and Published by

SPIE

Volume 8750 
The papers included in this volume were part of the technical conference cited on the cover and title page. Papers were selected and subject to review by the editors and conference program committee. Some conference presentations may not be available for publication. The papers published in these proceedings reflect the work and thoughts of the authors and are published herein as submitted. The publisher is not responsible for the validity of the information or for any outcomes resulting from reliance thereon.

Please use the following format to cite material from this book:

Author(s), "Title of Paper," in Independent Component Analyses, Compressive Sampling, Wavelets, Neural Net, Biosystems, and Nanoengineering XI, edited by Harold H. Szu, Proceedings of SPIE Vol. 8750 (SPIE, Bellingham, WA, 2013) Article CID Number.

ISSN: 0277-786X

ISBN: 9780819495419

Published by

SPIE

P.O. Box 10, Bellingham, Washington 98227-0010 USA

Telephone +1 3606763290 (Pacific Time) · Fax +1 3606471445

SPIE.org

Copyright (C) 2013, Society of Photo-Optical Instrumentation Engineers.

Copying of material in this book for internal or personal use, or for the internal or personal use of specific clients, beyond the fair use provisions granted by the U.S. Copyright Law is authorized by SPIE subject to payment of copying fees. The Transactional Reporting Service base fee for this volume is $\$ 18.00$ per article (or portion thereof), which should be paid directly to the Copyright Clearance Center (CCC), 222 Rosewood Drive, Danvers, MA 01923. Payment may also be made electronically through CCC Online at copyright.com. Other copying for republication, resale, advertising or promotion, or any form of systematic or multiple reproduction of any material in this book is prohibited except with permission in writing from the publisher. The CCC fee code is 0277-786X/13/\$18.00.

Printed in the United States of America.

Publication of record for individual papers is online in the SPIE Digital Library.

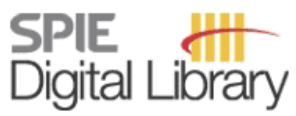

SPIEDigitalLibrary.org

Paper Numbering: Proceedings of SPIE follow an e-First publication model, with papers published first online and then in print and on CD-ROM. Papers are published as they are submitted and meet publication criteria. A unique, consistent, permanent citation identifier (CID) number is assigned to each article at the time of the first publication. Utilization of CIDs allows articles to be fully citable as soon as they are published online, and connects the same identifier to all online, print, and electronic versions of the publication. SPIE uses a six-digit CID article numbering system in which:

- The first four digits correspond to the SPIE volume number.

- The last two digits indicate publication order within the volume using a Base 36 numbering

system employing both numerals and letters. These two-number sets start with 00, 01, 02, 03, 04, $05,06,07,08,09,0 A, 0 B \ldots 0 Z$, followed by 10-1Z, 20-2Z, etc.

The CID Number appears on each page of the manuscript. The complete citation is used on the first page, and an abbreviated version on subsequent pages. Numbers in the index correspond to the last two digits of the six-digit CID Number. 


\title{
Contents
}

\author{
ix Conference Committee \\ xiii Introduction
}

\section{SESSION 1 WAVELET PIONEER AWARD}

875002 Group theoretical methods and wavelet theory: coorbit theory and applications (Invited Paper) [8750-1]

H. G. Feichtinger, Univ. Wien (Austria)

\section{SESSION 2 ROBUSTNESS WAVELET APPLICATIONS}

875003 Composite wavelet representations for reconstruction of missing data (Invited Paper) [8750-2]

W. Czaja, J. Dobrosotskaya, B. Manning, Univ. of Maryland, College Park (United States)

875004 Tight frames for multiscale and multidirectional image analysis (Invited Paper) [8750-3] E. H. Bosch, A. Castrodad, J. S. Cooper, National Geospatial-Intelligence Agency (United States); W. Czaja, J. Dobrosotskaya, Univ. of Maryland (United States)

\section{SESSION 3 MULTIRESOLUTION APPLICATIONS}

875006 Emotional state and its impact on voice authentication accuracy (Invited Paper) [8750-5] M. Voznak, P. Partila, M. Penhaker, T. Peterek, K. Tomala, F. Rezac, J. Safarik, VŠB-Technical Univ. of Ostrava (Czech Republic)

\section{SESSION 4 UNSUPERVISED LEARNING ICA PIONEER AWARD}

875007 Audio source separation with multiple microphones on time-frequency representations (Invited Paper) [8750-6]

H. Sawada, NTT Communication Science Labs. (Japan)

\section{SESSION $5 \quad$ NEURAL NETWORK LEARNING APPLICATION}

875008 Optimization of object region and boundary extraction by energy minimization for activity recognition [8750-7]

F. A. Albalooshi, V. K. Asari, Univ. of Dayton (United States) 
875009 Automated analysis of spatio-temporal features for non-masses [8750-8]

S. Hoffmann, Univ. des Saarlandes (Germany); M. Lobbes, Maastricht Univ. Medical Ctr.

(Netherlands); B. Burgeth, Univ. des Saarlandes (Germany); A. Meyer-Bäse, The Florida

State Univ. (United States)

SESSION $6 \quad$ UNSUPERVISED LEARNING NEURAL NETS AND ICA

8750 0A Wavelet neural networks for stock trading (Invited Paper) [8750-9]

T. Zheng, K. Fataliyev, L. Wang, Nanyang Technological Univ. (Singapore)

8750 0C Artificial neural networks (ANNs) compared to partial least squares (PLS) for spectral interference correction in optical emission spectrometry (Invited Paper) [8750-11]

Z. Li, X. Zhang, V. Karanassios, Univ. of Waterloo (Canada)

8750 OD Analysis and removing noise from speech using wavelet transform [8750-12]

K. Tomala, M. Voznak, P. Partila, F. Rezac, J. Safarik, VŠB-Technical Univ. of Ostrava (Czech Republic)

SESSION 7 COMPRESSIVE SAMPLING PIONEER AWARD

$8750 \mathrm{OE} \quad$ Multichannel blind deconvolution using low rank recovery (Invited Paper) [8750-13]

J. Romberg, N. Tian, K. Sabra, Georgia Institute of Technology (United States)

\section{SESSION $8 \quad$ COMPRESSIVE SAMPLING APPLICATIONS I}

8750 OF Passive ranging redundancy reduction in diurnal weather conditions [8750-14]

J. H. Cha, A. L. Abbott, Virginia Polytechnic Institute and State Univ. (United States);

H. H. Szu, The Catholic Univ. of America (United States)

8750 0G Feature-organized sparseness for efficient face recognition from multiple poses [8750-15]

T. Iwamura, Japan Ministry of Defense (Japan)

$8750 \mathrm{OH} \quad$ Adaptive sparse signal processing of on-orbit lightning data using learned dictionaries [8750-16]

D. I. Moody, D. A. Smith, T. D. Hamlin, T. E. Light, D. M. Suszcynsky, Los Alamos National Lab. (United States)

\section{SESSION 9 COMPRESSIVE SAMPLING APPLICATIONS II}

8750 OJ Hyperspectral waveband group optimization for time-resolved human sensing [8750-18] B. Kaur, V. A. Hodgkin, U.S. Army RDECOM CERDEC, NVESD (United States); J. K. Nelson, V. N. Ikonomidou, George Mason Univ. (United States); J. A. Hutchinson, U.S. Army RDECOM CERDEC, NVESD (United States)

8750 OK Decoupling sparse coding of SIFT descriptors for large-scale visual recognition [8750-19] Z. Ji, J. Theiler, R. Chartrand, G. Kenyon, S. P. Brumby, Los Alamos National Lab. (United States) 
$8750 \mathrm{OL}$ A study of the coherence parameter of the progressive compressive imager based on radon transform [8750-20]

V. Farber, E. Eduard, Y. Rivenson, A. Stern, Ben Gurion Univ. of the Negev (Israel)

$8750 \mathrm{OM}$ Super-resolution reconstruction of compressed sensing mammogram based on contourlet transform [8750-21]

Y. Shen, H. Chen, C. Yao, Beijing Jiaotong Univ. (China); Z. Qiao, The Univ. of Texas-Pan American (United States)

$8750 \mathrm{ON}$ Noise synthetic aperture radar (SAR) imagery compressing and reconstruction based on compressed sensing [8750-22]

H. Zhao, Hengyang Normal Univ. (China) and The Univ. of Texas-Pan American (United

States); J. F. Lopez Jr., S. Li, Y. Cao, Z. Qiao, The Univ. of Texas-Pan American (United States)

\section{SESSION 10 NANOENGINEERING AND IMPLEMENTATION AWARD}

$875000 \quad$ Three dimensional self-assembly at the nanoscale (Invited Paper) [8750-23]

D. H. Gracias, Johns Hopkins Univ. (United States)

\section{SESSION 11 IMPLEMENTATION}

$8750 \mathrm{OQ}$ Optimization of block-matching algorithms using custom instruction-based paradigm on NIOS II microprocessors [8750-25]

D. González, The Florida State Univ. (United States); G. Botella, The Florida State Univ. (United States) and Univ. Complutense de Madrid (Spain); A. Meyer-Bäse, U. Meyer-Bäse, The Florida State Univ. (United States)

8750 OR CAD-system based on kinetic analysis for non-mass-enhancing lesions in DCE-MRI [8750-26]

S. Goebl, Ludwig-Maximilians-Univ. München (Germany); C. Plant, Technische Univ. München (Germany); M. Lobbes Maastricht Univ. Medical Ctr. (Netherlands);

A. Meyer-Bäse, The Florida State Univ. (United States)

8750 OS A modified PSO based particle filter algorithm for object tracking [8750-27]

Y. Tang, The Univ. of Rhode Island (United States); S. Fu, Minzu Univ. of China (China);

B. Tang, H. He, The Univ. of Rhode Island (United States)

8750 OT Visual saliency approach to anomaly detection in an image ensemble [8750-28]

A. Singh, M. A. Pratt, C.-H. H. Chu, Univ. of Lovisiana at Lafayette (United States)

8750 OU Fast algorithm for entropy estimation [8750-29]

E. A. Timofeev, Yaroslavl State Univ. (Russian Federation); A. Kaltchenko, Wilfrid Laurier Univ. (Canada) 
8750 OV Low-rank modeling and its applications in medical image analysis (Invited Paper)

[8750-30]

X. Zhou, W. Yu, The Hong Kong Univ. of Science and Technology (Hong Kong, China)

\section{SESSION $13 \quad$ BIOMEDICAL WELLNESS APPLICATIONS II}

8750 OW Adaptive compressive sensing camera [8750-17]

C. Hsu, M. K. Hsu, The George Washington Univ. (United States); J. Cha, Virginia Polytechnic Institute and State Univ. (United States); T. Iwamura, Japan Ministry of Defense (Japan); J. Landa, BriarTek, Inc. (United States); C. Nguyen, H. Szu, The Catholic Univ. of America (United States)

8750 OX Visual analysis and dynamical control of phosphoproteomic networks (Invited Paper) [8750-32]

A. Meyer-Bäse, R. Görke, The Florida State Univ. (United States); M. Lobbes, Maastricht Univ. Medical Ctr. (Netherlands); M. R. Emmett, C. L. Nilsson, The Univ. of Texas Medical Branch (United States)

\section{SESSION 14 BIOMEDICAL WELLNESS APPLICATIONS III}

8750 OY Monitoring and diagnosis of Alzheimer's disease using noninvasive compressive sensing EEG (Invited Paper) [8750-35]

F. C. Morabito, D. Labate, Univ. Mediterranea di Reggio Calabria (Italy); G. Morabito, Univ. degli Studi di Pavia (Italy); I. Palamara, Univ. Mediterranea di Reggio Calabria (Italy);

H. SzU, The Catholic Univ. of America (United States)

$8750 \mathrm{OZ}$ Health sensor for human body by using infrared, acoustic energy and magnetic signature [8750-34]

J. Wu, The George Washington Univ. (United States)

875011 Theory of compressive modeling and simulation [8750-44]

H. Szu, The Catholic Univ. of America (United States); J. Cha, Virginia Polytechnic Institute and State Univ. (United States); R. L. Espinola, Columbia Univ. (United States); K. Krapels, Univ. of Tennessee (United States)

\section{SESSION $15 \quad$ SYSTEMS OF BIOLOGY AWARD}

875012 Self-organization of neural patterns and structures in 3D culture of stem cells (Invited Paper) [8750-37]

Y. Sasai, RIKEN (Japan) 
875013 Understanding 3D human torso shape via manifold clustering [8750-38]

S. Li, Northeastern Univ. (United States); P. Li, U.S. Army Natick Soldier Research,

Development and Engineering Ctr. (United States); Y. Fu, Northeastern Univ. (United States)

875014 Inclusion principle for statistical inference and learning [8750-39]

$X$. Chen, Southern Univ. and A\&M College (United States)

875015 Simultaneous inference of population proportions and its applications in machine learning [8750-40]

X. Chen, Southern Univ. and A\&M College (United States)

875016 Entropy estimation and Fibonacci numbers [8750-41]

E. A. Timofeev, Yaroslavl State Univ. (Russian Federation); A. Kaltchenko, Wilfrid Laurier Univ. (Canada)

875017 Augmented reality for biomedical wellness sensor systems [8750-42]

J. Jenkins, George Mason Univ. (United States); H. Szu, The Catholic Univ. of America (United States)

Author Index 


\title{
Conference Committee
}

\author{
Symposium Chair
}

Kenneth R. Israel, Major General (USAF Retired) (United States)

Symposium Cochair

David A. Whelan, Boeing Defense, Space, and Security

(United States)

Conference Chair

Harold H. Szu, The Catholic University of America (United States)

Conference Program Committee

Shun-ichi Amari, RIKEN (Japan)

Richard G. Baraniuk, Rice University (United States)

John J. Benedetto, University of Maryland, College Park

(United States)

Henry Chu, University of Lovisiana at Lafayette (United States)

Ronald R. Coifman, Yale University (United States)

John Daugman, University of Cambridge (United Kingdom)

David Donohoe, Stanford University (United States)

Ronald G. Driggers, U.S. Naval Research Laboratory (United States)

Jide Familoni, U.S. Army Night Vision \& Electronic Sensors Directorate (United States)

Fredric M. Ham, Florida Institute of Technology (United States)

Yutaka Hata, University of Hyogo (Japan)

Charles C. Hsu, Trident Systems Inc. (United States)

Tzyy-Ping Jung, University of California, San Diego (United States)

Marc W. Kirschner, Harvard Medical School (United States)

Keith A. Krapels, U.S. Army Night Vision \& Electronic Sensors

Directorate (United States)

Horacio Lamela, Universidad Carlos III de Madrid (Spain)

Joseph S. Landa, BriarTek, Inc. (United States)

Douglas A. Lauffenburger, Massachusetts Institute of Technology (United States)

Soo-Young Lee, KAIST (Korea, Republic of)

Kevin W. Lyons, National Institute of Standards and Technology (United States)

Anke D. Meyer-Bäse, The Florida State University (United States)

Uwe Meyer-Bäse, The Florida State University (United States) 
Francesco Carlo Morabito, Universitá Mediterranea di Reggio

Calabria (Italy)

Hiroshi Nakajima, OMRON Corp. (Japan)

Hyung-Min Park, Sogang University (Korea, Republic of)

Kitt C. Reinhardt, Air Force Office of Scientific Research

(United States)

Zuowei Shen, National University of Singapore (Singapore)

Metin Sitti, Carnegie Mellon University (United States)

Jan-Olov Stromberg, Royal Institute of Technology (Sweden)

John Tangney, Office of Naval Research (United States)

Emmanuel Vincent, IRISA / INRIA Rennes (France)

Nadarajen A. Vydelingum, National Institutes of Health

(United States)

Lipo Wang, Nanyang Technological University (Singapore)

Olaf Wolkenhaver, Universität Rostock (Germany)

Donald C. Wunsch II, Missouri University of Science and Technology

(United States)

Ning Xi, Michigan State University (United States)

Takeshi Yamakawa, Fuzzy Logic Systems Institute (Japan)

Yiping Zhao, The University of Georgia (United States)

Yufeng Zheng, Alcorn State University (United States)

Xiaowei Zhuang, Harvard University (United States)

Session Chairs

1 Wavelet Pioneer Award

John J. Benedetto, University of Maryland, College Park

(United States)

Zuowei Shen, National University of Singapore (Singapore)

2 Robustness Wavelet Applications

John J. Benedetto, University of Maryland, College Park (United States)

3 Multiresolution Applications

Hans G. Feichtinger, Universität Wien (Austria)

4 Unsupervised Learning ICA Pioneer Award

Emmanuel Vincent, IRISA / INRIA Rennes (France)

Soo-Young Lee, KAIST (Korea, Republic of)

Tzyy-Ping Jung, University of California, San Diego (United States)

5 Neural Network Learning Application

Hiroshi Sawada NTT Communication Science Laboratories (Japan)

Harold H. Szu, The Catholic University of America (United States) 
6 Unsupervised Learning Neural Nets and ICA

Hiroshi Sawada, NTT Communication Science Laboratories (Japan)

Harold H. Szu, The Catholic University of America (United States)

7 Compressive Sampling Pioneer Award

John J. Benedetto, University of Maryland, College Park (United States)

8 Compressive Sampling Applications I

Justin K. Romberg, Georgia Institute of Technology (United States)

9 Compressive Sampling Applications II

Justin K. Romberg, Georgia Institute of Technology (United States)

10 Nanoengineering and Implementation Award

Yiping Zhao, The University of Georgia (United States)

Uwe Meyer-Bäse, The Florida State University (United States)

11 Implementation

Henry Chu, University of Louisiana at Lafayette (United States)

Uwe Meyer-Bäse, The Florida State University (United States)

12 Biomedical Wellness Applications I Award

Lipo Wang, Nanyang Technological University (Singapore)

Anke Meyer-Bäse, The Florida State University (United States)

Jide Familoni, U.S. Army Night Vision \& Electronic Sensors Directorate (United States)

13 Biomedical Wellness Applications II

Jide Familoni, U.S. Army Night Vision \& Electronic Sensors Directorate (United States)

Hiroshi Nakajima, OMRON Corp. (Japan)

14 Biomedical Wellness Applications III

Jide Familoni, U.S. Army Night Vision \& Electronic Sensors Directorate (United States)

Yutaka Hata, University of Hyogo (Japan)

15 Systems of Biology Award

Nadarajen A. Vydelingum, National Institutes of Health (United States)

Anke Meyer-Bäse, The Florida State University (United States)

Shun-ichi Amari, RIKEN (Japan)

Fredric M. Ham, Florida Institute of Technology (United States) 
16 Systems Applications

Nadarajen A. Vydelingum, National Institutes of Health (United States)

Anke Meyer-Bäse, The Florida State University (United States)

Fredric M. Ham, Florida Institute of Technology (United States)

Panel Discussion on Robustness of Orthogonal Versus Non-Orthoganal Wavelets Concentration of Signal Energy

Zuowei Shen, (Moderator) National University of Singapore (Singapore)

Soo-Young Lee, (Moderator) KAIST (Korea, Republic of)

Harold H. Szu, (Moderator) The Catholic University of America

(United States)

Panel Discussion: Why are pre-processing and post-processing necessary for unsupervised learning?

Hiroshi Sawada, (Moderator) NTT Communication Science Laboratories (Japan)

Soo-Young Lee, (Moderator) KAIST (Korea, Republic of)

Panel Discussion: Difference of Pre-Processing versus Post-Processing, i.e, JPEG2000 Compression versus CRTD Compressive Sensing

Justin K. Romberg, (Moderator) Georgia Institute of Technology

(United States)

Panel Discussion: Nano-enhancement of Moore's Law

David Gracias, (Moderator) John Hopkins University (United States)

Yiping Zhao, (Moderator) The University of Georgia (United States)

Ning Xi, (Moderator) Michigan State University (United States)

Panel Discussion: Why don't insurance companies support homecare technology for an aging society?

Lipo Wang, (Moderator) Nanyang Technological University (Singapore)

Weichuan Yu, (Moderator) Hong Kong University of Technology (Hong Kong)

Panel Discussion: Laissez faire stem cells (leave us be, let us do): medicine from the organ self repairmen perspective

Nadarajen A. Vydelingum, (Moderator) National Institutes of Health (United States)

Anke D. Meyer-Bäse, (Moderator) The Florida State University (United States) 


\section{INTRODUCTION}

HUMAN COMPONENTS SCIENCE (http://www.ica-wavelet.org)

The 2013 conference: "Independent Component Analyses, Compressive Sampling, Wavelets, Neural Net, Biosystems, and Nanoengineering, XI" was held from May $1^{\text {st }}$ to May $3^{\text {rd }}$ at the Baltimore Convention Center. Three days were divided into 6 tracks. We introduced human sciences as component tracks, and integrated them together as an interdisciplinary endeavor over the decades since SPIE Aerosense Symposium in Orlando. Thanks to the efforts of our Web Master, Professor Yufeng Zheng who committed his own financial resources and know-how to design and update the www.ica-wavelet.org website, our decades-old activity in the educational research and development forum are now recorded and available. Our conference proceedings are one of the most timely and sought-after review publications in the standing order of worldwide libraries. We strongly encourage our Pioneer Award recipients to author comprehensive reviews of their work for the worldwide interdisciplinary readership adding to the impact. Albert Einstein once said to a celebrated educator, physicist George Uhlenbeck that "science has nothing to do with the truth but with consistency;" but "a terrible thing to waste in science is a developing young mind." Our human component science rightly belongs in the SPIE Defense, Security, and Sensing (DSS) Symposium because in a broad sense, DSS is against the worst enemies of mankind.

We capture the human sciences in various components in the SPIE proceedings over the last decades. They included: (i) sensor-like ears \& eyes in adaptive wavelets, (ii) brain-like unsupervised learning and independent component analysis; (iii) compressive sampling in spatiotemporal sparse processing, (iv) nanoengineering approach to measure the components; $(v)$ biomedical wellness applications; and ( $v$ ) system of systems biology. All and all we wish to learn from Mother Nature a system of systems that can interact in a nonlinear competitive and cooperative synergism called a dynamic programming. The design by iterative Kalman-like filter concept led naturally to wavelets by Kohonen Self Organization Feature Map in a higher dimensionality. The Artificial Neural Network Learning evolves towards unsupervised learning resembling some declutter Independent/dependent Component Analysis (ICA) functionality of our brains. Compressive sampling may emulate brain-like storage (at hippocampus associative memory); DNA genetic coding together with epic-genetic adaptation is relevant to the core application of nanotechnology implemented by Nanoengineering. Human Biomedical wellness requires the understanding of a system of biological sub-systems, which behaves like a real-world complex, nonlinear, robust dynamics.

In other words, we need to broaden our concepts and tools beyond college linear algebra, to understand one another. Together we can serve the 
interdisciplinary community better. Thus, as conference facilitators we have incorporated the compressive sampling pioneer award in 2012. Every year we try to do our best, without financial resources but with our sincerity, to invite the best of the best to give us the lectures. How did we do the track continuously? We learned from the Nobel Laureates Foundation. Conference chairs became only the facilitator, not financier nor managers, we let "the former recipients with their scientific and personnel relationship to influence and secure the next recipient(s)" to deliver their review talks. Since SPIE has a 20 minutes hopping unit for audiences, we suggested 2 units per an invited talk and 1 unit panel for $Q$ \& A. The total length would satisfy the need to prepare material for a 60 minute class.

We are grateful to the previous year award recipients, and wish to thank all six of them again. 2011 recipeints: John Benedetto (Univ. Maryland); Metin Sitti (CMU); Hiroshi Nakajima (Omron Inc.); Doug Lauffenburger (MIT); Soo-Young Li (KAIST); and Hyung-Min Park (Sogang U.). They headed each track and its selection processes for 2012 year's 6 awardees and a special leadership award was given to by John F. Tangney (Office of Naval Research). The 2012 recipients were: in Wavelets: Zuowei Shen (Nat. Univ. Singapore); in unsupervised learning ICA: Emmanuel Vincent (IRISA, France); in Compressive Sampling: Richard Baraniuk (Rice Univ.); in Nano-Engineering: Yiping Zhao (Univ. Georgia); in Biomedical wellness: Lipo Wang (Nanyang Tech. Univ., Singapore); In Systems of Biology: Xiaowei Zhuang (Harvard Univ.).

The World-Class scientists invited to the Baltimore Convention Center this year, were selected by the aforementioned 2012-recipients serving as the track chairs: Shen, Vinvent, Baranuik, Wang, Zhuang:

(1) Wavelet: Hans G. Feichtinger, University of Vienna, Austria spoke about group theoretical methods and wavelet theory.

(2) ICA Unsupervised Learning: Hiroshi Sawada, NTT Communication Science Lab, Japan, spoke and demonstrated on the spot multiple microphone and multiple speakers de-mixing speeches.

(3) Compressive Sampling: Justin Romberg, GIT, Blind de-convolution using convex programming.

(4) Nanoengineering: David Gracias, John Hopkins University spoke about 3D self assembly.

(5) Biomedical Wellness: Weichuan Yu, Hong Kong Univ. of Science and Technology

(6) Systems of Biology: Yoshiki Sasai, RIKEN, Kobe, Japan, spoke about embryonic stem cells self assembly model. Dr. Yoshiki Sasai (Nature, 472, 51-56, 07 April 2011 ) will receive his worldwide recognition, if his embryonic stem cell growth protocol of 6-layer optical cup of human eye in vitro were also be able to apply in vivo in Parkinson disease. 
From nature, we learned that change is the norm, and adaptation means survival. We are on an evolutional process to change the wavelet track to something bigger and better. The first conference in this wavelet series was incepted in 1994 by few colleagues in ONR called "Wavelets applications" as a part of Aerosense annual symposium held by SPIE at Orlando during Easter week. We followed the leadership of Applied Computational Mathematics Program (DARPA PM Helena Wiesniewski and PM Ira Skurnick) selected the first Wavelet Pioneer Recipient Stephan Mallat, and Ingrid Daubechies. Then, the recipients gradually evolve from wavelets mathematics towards adaptive wavelets are like human ears and eyes in an over-determined \& non-orthogonal set. Then, several years later, the recipient Dr. Swelden promoted the Next Gen Wavelets for a natural generalization to a higher dimensionality graphic filter bank. Wavelet Pioneer Award has dealt with Multiple Resolution Analysis (MRA). We are thinking MRA could help the redundancy reduction, similar to the counting strategy after sorting data in wavelet transform used in Compressive Sensing. We realized the challenges of reducing the redundancy and revealing the sparseness are necessary for living in a curse digital society. We may call, instead of MRA, replacing two letters $M$ of multiple, $R$ of resolution to $M$ for Massive and $D$ for data, as well as Analysis with Harmonic Analyses. We have Harmonic Analysis and Massive Data (HAMD) that can attract federal R/D resources admitting modern operation research tools and math representations (Raphy Coifman's Nonlinear Dimensionality Reduction, Daubechies-Mallat Fourier-Wavelet transforms, and Benedetto and Feichtinger's Harmonic analyses, as well as Daugman's Gabor Billions Iris Analyses). If so agreed on Harmonic Analysis and Massive Data (HAMD), we will recommend SPIE Conference Education Coordinator to support CS awards with a short course by Justin Romberg with a rapid medical imaging taken from 20 minutes to one minute, and HAMD awards in turns by John Benedetto about harmonic analysis and wavelets, and Waichuan Yu for low rank \& sparse novelty, as well as Anke Meyer-Baese for data mining in Bionmics.

Harold H. SzU 